European Journal of Accounting, Auditing and Finance Research

Vol.8, No.4, pp.1-17, April 2020

Published by ECRTD-UK

Print ISSN: 2053-4086(Print), Online ISSN: 2053-4094(Online)

\title{
CORPORATE SOCIAL RESPONSIBILITY PRACTICES AND REPUTATION OF LISTED FIRMS IN NIGERIA: A STRUCTURAL EQUATION MODELING APPROACH
}

\author{
Adekoya, O. B.Sc., M.Sc. \\ Babcock University, Department of Accounting, Nigeria \\ fmadekoya@yahoo.com \\ Enyi, P. Enyi, PhD. \\ Professor of Accounting, Former Dean, School of Management Sciences, Babcock University, \\ Nigeria. \\ enyip@babcock.edu.ng

\begin{abstract}
Akintoye, I.R. PhD.
Professorial chair for Chartered Institute of Taxation of Nigeria at Babcock University, Nigeria akintoyer@babcock.edu.ng
\end{abstract} \\ Adegbie F.F. PhD. \\ Associate Professor, Head of Department of Accounting, Babcock University, Nigeria. \\ adegbief@ babcock.edu.ng
}

\begin{abstract}
With the advent of globalization, societal and economic concern increases; this did not give clear standards or regulations for measuring CSR that has been created by the organization. Thus many problems occur due to the inconsistency in which companies are capable of claiming activities that might not meet the general understanding of CSR initiatives. It may improve their reputation, or in some cases, companies do not have a clear understanding of what CSR means. Furthermore, the impacts of CSR practices on firms' reputation are not well delineated in the literature. Hence, this study examined the impact of CSR practices and reputation of listed firms in Nigeria. Primary data collected through the use of a structured and validated questionnaire. Cronbach's alpha reliability coefficients for the constructs ranged from 0.85 to 0.90. The response rate was $98 \%$. Data were analyzed using descriptive and inferential statistics. Findings revealed that corporate social responsibility had a positive and significant effect on business reputation ( $R 2=0.43, \beta=0.654, t(389)=15.697, p<0.05)$, Business ethics and innovation significantly moderated the relationship between CSR and business reputation $(\triangle A d j . R 2=0.562, \Delta F(3,386)=167.55, p<0.05)$ respectively. The study concluded that corporate social responsibility affects the corporate performance of firms in Nigeria. Recommended that the practice of corporate social responsibility should be intensified by corporate firms to improve on their performance.
\end{abstract}

KEYWORDS: business ethics, business reputation, corporate social responsibility, innovation. 
European Journal of Accounting, Auditing and Finance Research

Vol.8, No.4, pp.1-17, April 2020

Published by ECRTD-UK

Print ISSN: 2053-4086(Print), Online ISSN: 2053-4094(Online)

\section{INTRODUCTION}

The modern-day business environment is in the age of incoherence in which the changes occur on a continuous and disrupting basis. It makes it difficult for business firms to forecast future performance with precision. The changes may be minor or significant; nevertheless, it is important for a firm to evaluate how they can effectively cope with uncertainties in the levels of performance is the big contests (Selvam, Vasanth, Lingaraja \& marxiaoli, 2016). Management must incur some costs to be able to maintain the environment it operates to increase its performance. The degree of how much to use to maintain this disruptive activity is still an inconclusive discussion between academic researchers and practitioners (Selvam, Vasanth, Lingaraja \& marxiaoli, 2016; Richard, Devinney, Yip \& Johnson, 2009).

Firms need to show that it is their responsibility to eliminate the social costs created by their negative externalities caused by their economic activities, which are harmful to society. These are pollution to the environment, disregard of consumer rights, and general disregard for the welfare and well-being of stakeholders. The awareness of CSR has made it a mechanism of achieving competitive advantage, not only voluntarily but as a necessity for sustainable development in the competitive markets. CSR enables firms to maintain good relationships with the primary stakeholder, such as customers and employees, assisting them in developing intangible, valuable assets. These can be sources of competition by taken advantage of the environment and society to improve their reputation as a responsible corporate citizens (Valjakka, 2013; Masaka, 2008; Hillman and Keim, 2001).

With the advent of societal and economic concerns, there are inconclusive standards or regulations for measuring CSR that was develop. Problems occur due to the inconsistency in which companies are capable of claiming activities that might not meet the general understanding of CSR initiatives, which may improve their business reputation, or in some cases, companies do not have a clear understanding of CSR. Considering the nature of business and the ultimate aim of profit maximization as confirmed by Friedmans theory of 1970 (maximization of shareholder's wealth theory), which stated that there is one and only one social responsibility of business, which is to use its resources and engage in activities designed to increase its profit (Valjakka, 2013). Most academic literature claims that innovative activities linked to higher company performance, and the determinants of creative performance, that is, the magnitude of the economic returns of innovation, have attracted considerable academic interest (Saez-Martinez, Gonzalez-Moreno \& Hogan, 2014).

The literature made it known that there is an inconclusive understanding of how CSR initiatives may improve organizational performance through innovation. CSR initiatives argued that it might lead to change through ethics drivers to create new products, services, processes, and or new market space, which may encourage firms to redefine their business strategies. This innovation 
may be communicated and transferred to other organizations through the supply chain, which creates a virtuous circle. The existence and the nature of the relationship between CSR and performance are even less clear when CSR strategies and practices adopted by the organization (Cho, Chung \& Young, 2019; Morsing \& Perrini, 2009). Hence, this evidence suggested that both innovation and CSR should be considered important as a determinants indicators for firms' performance; studies empirically addressing their joint effects on performance are limited (Gonzalez-Ramos, Donate \& Guadamillas, 2014).

The constraints confronting businesses in Nigeria within the present complex and competitive environment are products of economic and non-economic related dimensions. To survive and prosper within the business environment, firms must plan their activities in such a way that they can strike a balance between CSR dimensions on business reputations (Jibril, Dahiru, Mukta \& Bello, 2016).

However, there is an inconclusive study on the influence of CSR practices with specific reference to business reputation in Nigeria, as well as business innovation and ethics. Thus, this study set out to achieve two objectives. First, evaluate the impact of corporate social responsibility on a reputation of listed firms in Nigeria; second, examine the controlling effect of innovations and business on the relationship between corporate social responsibility and reputation of listed firms in Nigeria. The hypothesis developed in line with the objective. Corporate Social Responsibility does not have significant effects on the reputation of listed firms in Nigeria. Thus, the kernel of this paper is to use a structural equation model to examine the impact of corporate social responsibility on the reputation of listed firms in Nigeria. The next section focuses on the literature review; section three discusses the research methodology and data collection. The last part provides findings, implications, and suggestions for future research.

\section{LITERATURE REVIEW}

Business reputation is known as general and combined gratitude, awareness, approach, and assessment of firms for a period concerning all involved stakeholder groups based on particular firm's worth, past performance, communication, representation and possibility and potential to satisfy future needs comparing to competitors (Petkeviciene, 2015; Zhou, Quan, \& Jiang, 2012). Reputation is firm's most cherished asset, and it is essential to recognize that any negative influence on reputation can damage the profitability for years ahead if they lose the confidence their stakeholders such as shareholders, customers, employees, suppliers or potential investors, government due to shareholder and customer confidence due to variability in the value of the firm's reputation. The negative impact may lead to business risks that the firms may face every day when they are interacting with stakeholders; whether they are dealing with the government, potential investors who intended to invest in their stocks or customers is buying their products (Valjakka, 2013). 
Where stakeholders' expectations have not achieved, the decrease in quality of business reputation will continue to reveal itself, which may affect the performance of firms through a decline in incomes. The decrease inability to attract financial institutions for sources of funds, current and potential employees will not be encouraged in contributing to the improvement of firms' productivity. These may lead to firms losing their stakeholder's confidence, which will affect their reputation and long-term performance (Valjakka, 2013; Fombrun, Gardberg \& Barnett, 2000).

The impression stakeholders have on firms matters; because various stakeholders have different feelings about firms' activities, some have good attitudes, some have a lousy mood, and others may not have any opinions about their activities. All the stakeholders will be having different thoughts for different missions because they have different ways of seeing the firms' operations. The overall global impressions that all these stakeholders have added up to firms' reputation, which they need to work on to create a good idea to the stakeholders (Veh, Gobel \& Vogel, 2018).

Minor and Morgan (2011) identified two different controls firms might use to improve their business reputation as a responsible corporate citizen. The first step is to embark on business activities that will benefit their environments, such as social causes in the form of donations to healthcare, employee welfare, scholarship to indigenes, and community developments to enable them to legitimate themselves with the society. The other one is to avoid harmful economic activities that may cause harm to the environment where they are operating (elimination of social costs by internalising all their negative externalities). In building firms', it can take several years, and destroying it may not take just one month or a day (Minor \& Morgan, 2011).

Changes in the business environment had shown that corporate social responsibility is significant for the sustainable development of companies. Scholarly research has emerged in the literature suggesting that corporate social responsibility idea is the key to motivate long-term stability, growth, and sustainable organizational performance in a vibrant and changing environment (Gyves \& O'Higgins, 2008; Luo \& Homburg, 2007).

Firms are looking for ways of improving their profits while maximizing shareholder's wealth. Firms are aware of the utility of an excellent innovative management approach that can allow them to strengthen their position in the market. For firms having innovative ideas will enable them suitable to meet the needs of shareholders and other stakeholders and also have a comparative advantage over competitors in the market, which can improve performance and boost business reputation (Conesa, Acosta, Manzano \& Jorge, 2007).

Business ethics is not just concerned about social obligations, but also obligations to employees, customers, suppliers, and competitors. CSR is about the extent to which firms' voluntary commitments to society at large (i.e., those who do not have direct involvement with the 
business). The normative stakeholder theory in CSR which draws its ideas from Ethics, that business corporations are morally responsible for looking after the concerns of a larger group of stakeholders which could include owners, customers, vendors, employees and community rather than its shareholders only (Goel \& Ramanathan, 2014; Wozniak 2011; Rodin 2005).

CSR has been part of ethical and responsible business practices; however, the concepts have gained power due to the globalization of the economic environment in today's business practices (Jamail \& Mirshak 2007). CSR operates on the principle that firms are obliged to meet their responsibilities to a broader array of stakeholders than its shareholders only. CSR should be integrated into business conducts, governance structure, and strategy. CSR activities across the world have increased dramatically in recent years as firms their value not only commercially but also in terms of boosting employee value, attracting staff, cutting costs, and improving business reputation (Goel, Sanghvi \& Dahiya 2013). CSR is considered to be a fee charged on the returns derived from the wrongs committed by a firm to pay for some of the rights, such as revenues collected by taxes associated with sin and exploitation are often earmarked for restoring health and the environmental development (Fuller 2013).

Ethical behaviour and corporate social responsibility can bring significant benefits to a business. The idea that business enterprises have some duties to society beyond that of making profits for shareholders has been around for centuries. It partly accounts for the reason why the concept of Corporate Social Responsibility (CSR) has continued to grow in importance and significance. One of the core beliefs is that business organizations have a social and ethical responsibility, as well as the economic mission of creating value for shareholders or owners of businesses (Carroll \& Shabana, 2010; Barry, 2000; Carroll, 1979).

Ethically running a business is the basic unit in a company to satisfy society. Economic responsibilities of business are to produce goods and services that the community needs and wants at a price that can prolong the continuing existence of the company, and also satisfy its obligations to investors. The ethical responsibilities are those behaviours or activities expected of businesses by society and other stakeholders such as; employees' welfare, increase in value for their shareholders and take care of the interests of different stakeholders (Carroll \& Shabana, 2010; Barry, 2000; Carroll, 1979).

CSR plays an essential role in a business environment, which can be regarded as a business strategy incorporated into firms' competitive advantage to have the edge over competitors in building and maintaining favourable corporate reputation (Park, Lee, \& Kim, 2014).

\section{METHODOLOGY}

The study adopted a survey research design with a population of 400 participants, where the primary method of data collection was adopted to collect the data from respondents that benefits 
Vol.8, No.4, pp.1-17, April 2020

Published by ECRTD-UK

Print ISSN: 2053-4086(Print), Online ISSN: 2053-4094(Online)

from the CSR. The response rate achieved was 98\%. Data were analyzed using descriptive and inferential statistics, using Partial Least Square for Structural Equation Model using SMART PLS 5 to test the relationship between the predictor variables on the dependent variables. The structural equation model was employed to examine the relationship between corporate social responsibilities and their impact on organizational performance measured by company reputation.

\section{RESULTS}

\section{Results}

Table 1: The Effects of Corporate Social Responsibility on Reputation of Listed Firms in Nigeria

Panel A: Long Run Coefficients

Dependent Variable: REP

\begin{tabular}{lllll}
\hline Variables & Coefficients & Standard Error & t-stat & Prob. \\
\hline CSR & 0.654 & 0.042 & 15.697 & 0.000
\end{tabular}

Panel B: Diagnostic Test

Stat Prob

\begin{tabular}{l}
\hline R-Square \\
Source 1: Researchers Computation (2020) \\
Note: Table: examine the impact of corporate social responsibility on reputation of listed firms in Nigeria. The dependent variable \\
is business reputation (REP) and the explanatory variable is corporate social responsibility (CSR). \\
The critical path analysis presented in Table one above shows the detailed outer loadings, \\
coefficients and the t-statistics.
\end{tabular}

\section{Interpretation}

$R E P_{i}=\alpha_{1} C S R_{i}+\varepsilon_{i}$

$R E P_{i}=0.654 C S R_{i}$

Table one above shows the results of structural equation estimates for the impact of corporate social responsibility on the reputation of listed firms in Nigeria. The results show that corporate social responsibility has a positive relationship with the reputation of listed firms in Nigeria. In addition, there is evidence that corporate social responsibility has significant relationship with reputation of listed firms in Nigeria $(\mathrm{CSR}=0.654$, $\mathrm{t}$-test $=15.697, \mathrm{p}<0.05)$. It implies that corporate social responsibility is a significant factor influencing changes in the reputation of listed firms in Nigeria. This result conforms with the work of Cherian, Umar, Thu, NguyenTrang, Sial and Khuong (2019) that analysed the impact of corporate social responsibility reporting on the financial performance of Indian companies. The results show that there is a significant relationship between the performance of Indian companies and CSR reporting. 
Vol.8, No.4, pp.1-17, April 2020

Published by ECRTD-UK

Print ISSN: 2053-4086(Print), Online ISSN: 2053-4094(Online)

Concerning the magnitude of the estimated parameters for the coefficient of the structural equation regression, a unit increase in corporate social responsibility will lead to 0.654 improvements in the reputation of listed firms. The R2, which measures the proportion of the changes in business reputation as a result of changes in corporate social responsibility, explains about 48 percent changes in the reputation of listed firms in Nigeria. In comparison, the remaining 52 percent were other factors explaining changes in the reputation of listed firms in Nigeria but not captured in the model. Based on the statistical significance of the t-test value of 15.697 at a 5 percent level, the null hypothesis that corporate social responsibility does not have significant effects on the reputation of listed firms in Nigeria rejected. Thus, the alternative hypothesis that corporate social responsibility does have a significant impact on the reputation of listed firms in Nigeria was accepted.

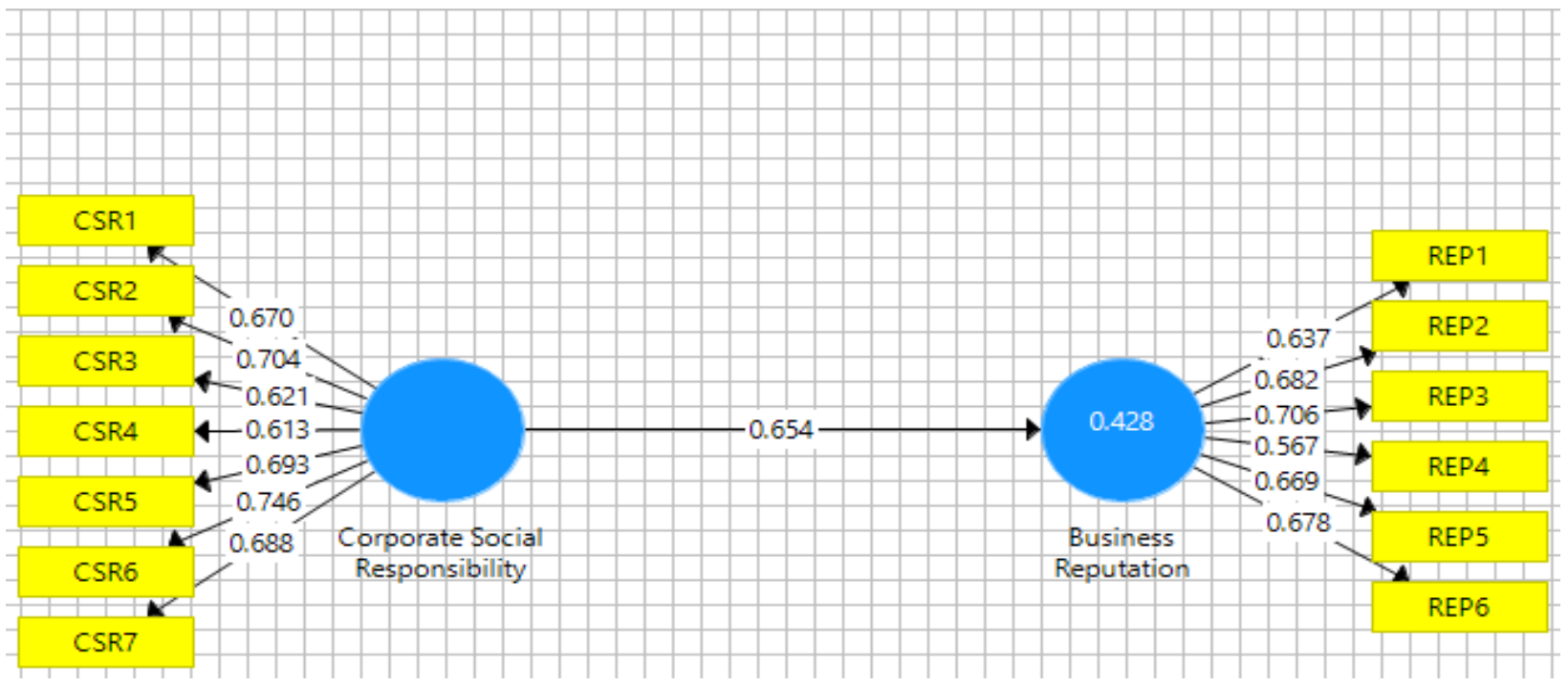

Source: Researchers Computation (2020)

Figure 1: Structural Equation Model Critical Path for the outer leadings and Parameter Estimates. 


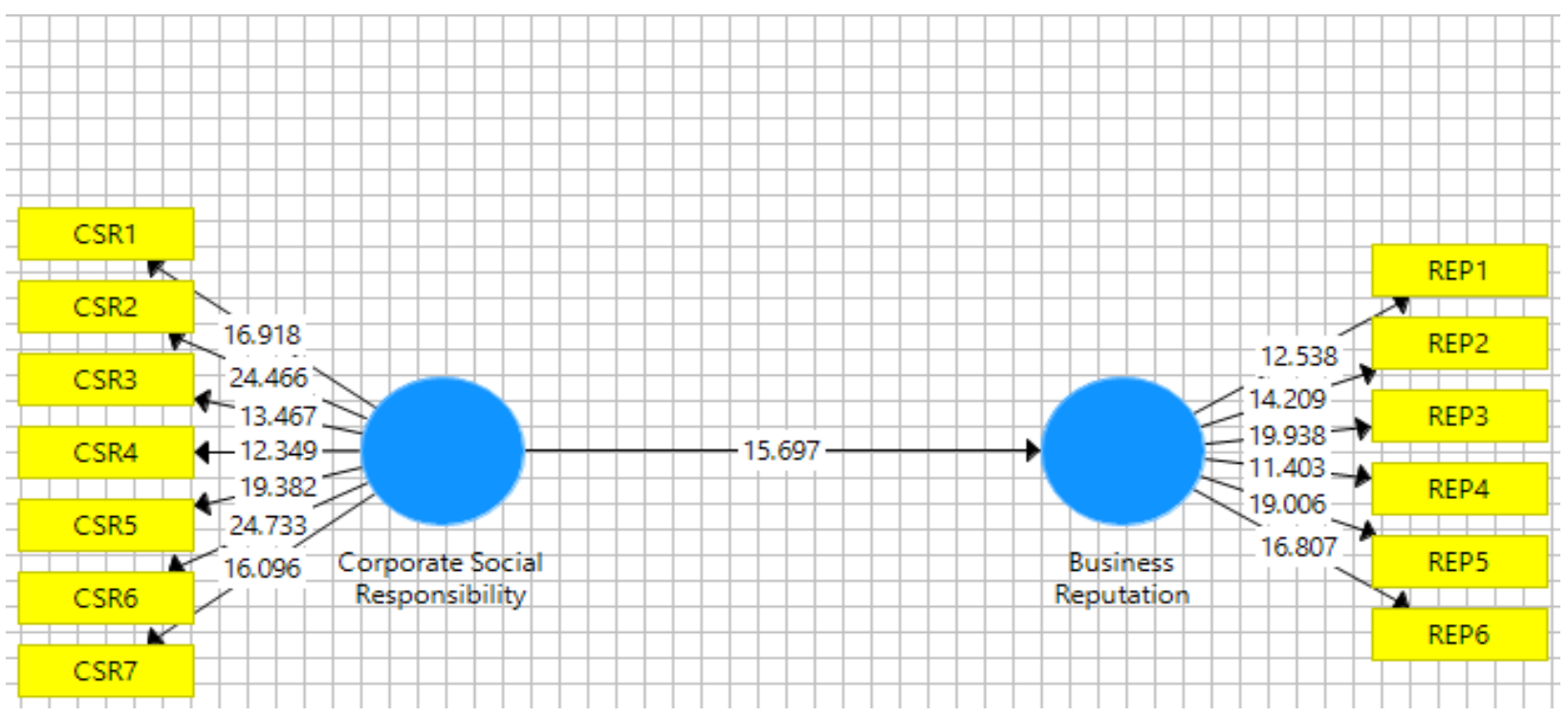

\section{Source: Researchers Computation (2020)}

Figure 2: Structural Equation Model Critical Path for the Level of Significance.

The Moderating Effect of Innovation and Business Ethics on the Relationship Between Corporate Social Responsibility on Reputation of Listed Firms in Nigeria

Table 2 Panel A: Long Run Coefficients

Dependent Variable: REP

\begin{tabular}{lllll}
\hline Variables & Coefficients & Standard Error & t-stat & Prob. \\
\hline BUETH & 0.208 & 0.063 & 3.276 & 0.001 \\
CSR & 0.299 & 0.062 & 4.815 & 0.000 \\
INNOV & 0.363 & 0.058 & 6.258 & 0.000
\end{tabular}

Panel B: Diagnostic Test

Stat Prob

Adjusted R-Square

0.562

F-Statistics

167.552

0.000

Source: Researchers Computation (2020)

Table 2 panel A examines the moderating effect of innovation and business ethics on the relationship between corporate social responsibility and company reputation. The dependent variable is business reputation (REP) and the explanatory variables are business ethics (BUETH), corporate social responsibility (CSR) and innovation (INNOV)

\section{Interpretation}

$R E P_{i}=\alpha_{1}$ BUETH $_{i}+\alpha_{2}$ CSR $_{i}+\alpha_{1}$ INNOV $_{i}+\varepsilon_{i}$

$R E P_{i}=0.208 B$ UETH $_{i}+0.299$ CSR $_{i}+0.363$ INNOV $_{i}$ 
Vol.8, No.4, pp.1-17, April 2020

Published by ECRTD-UK

Print ISSN: 2053-4086(Print), Online ISSN: 2053-4094(Online)

Table 2 shows the results of structural equation estimates for the moderating effect of innovation and business ethics on the relationship between corporate social responsibility and reputation of listed firms in Nigeria. The results show that business ethics, corporate social responsibility, and innovation have a positive relationship with the reputation of listed firms in Nigeria. In addition, there is evidence that business ethics, corporate social responsibility and innovation have significant relationship with reputation of listed firms in Nigeria (BUETH $=0.208 \mathrm{t}$-test $=3.276, \mathrm{p}$ $<0.05, \mathrm{CSR}=0.299$, t-test $=4.815, \mathrm{p}<0.05, \mathrm{INNOV}=0.363$, t-test $=6.258, \mathrm{p}<0.05)$ respectively. It implies that business ethics, corporate social responsibility, and innovation were significant factors influencing changes in the reputation of listed firms in Nigeria.

Concerning the magnitude of the estimated parameters for the coefficients of the structural equation regression, a unit increase in business ethics, corporate social responsibility, and innovation will lead to $0.208,0.299$, and 0.363 increases in business reputation, respectively.

The Adjusted R2, which measures the proportion of the changes in business reputation as a result of changes in business ethics, corporate social responsibility, and innovation, explains about 56 percent changes in the business reputation of quoted companies in Nigeria. At the same time, the remaining 44 percent were other factors explaining differences in the reputation of listed firms in Nigeria but not captured in the model.

In Panel B of Table 2, the F-Statistic of 167.552 is statistically significant at 5 percent level, thus on the overall. The null hypothesis of controlling variables of innovation and business ethics has no significant effect on the relationship between corporate social responsibility and company reputation is rejected. Thus, the alternative hypothesis that the controlling variables of innovation and business ethics have a significant effect on the relationship between corporate social responsibility and company reputation was accepted. 
European Journal of Accounting, Auditing and Finance Research

Vol.8, No.4, pp.1-17, April 2020

Published by ECRTD-UK

Print ISSN: 2053-4086(Print), Online ISSN: 2053-4094(Online)

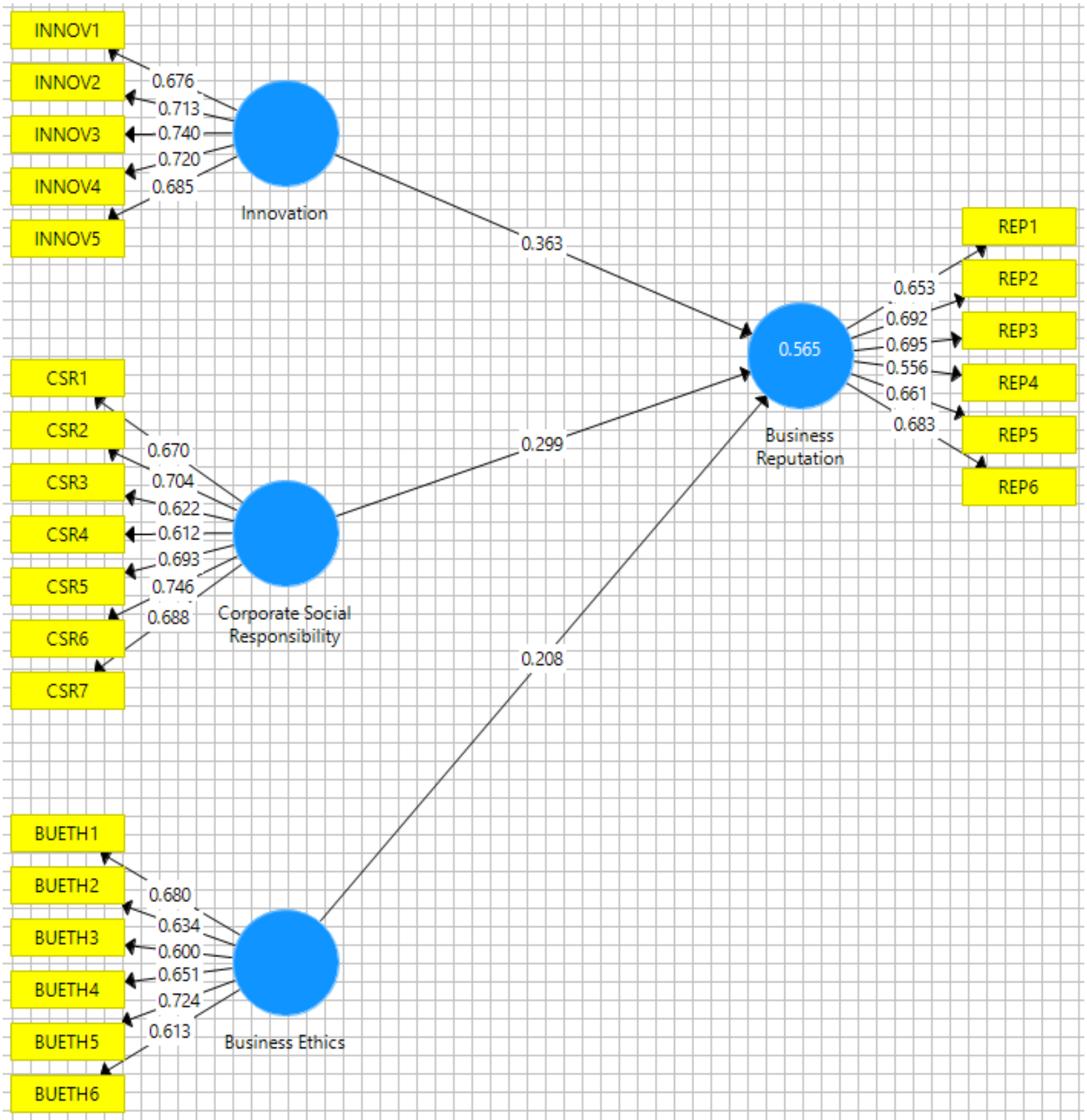

Source: Researchers Computation (2020)

Figure 3: Structural Equation Model Critical Path for the outer leadings and Parameter Estimates. 
European Journal of Accounting, Auditing and Finance Research

Vol.8, No.4, pp.1-17, April 2020

Published by ECRTD-UK

Print ISSN: 2053-4086(Print), Online ISSN: 2053-4094(Online)

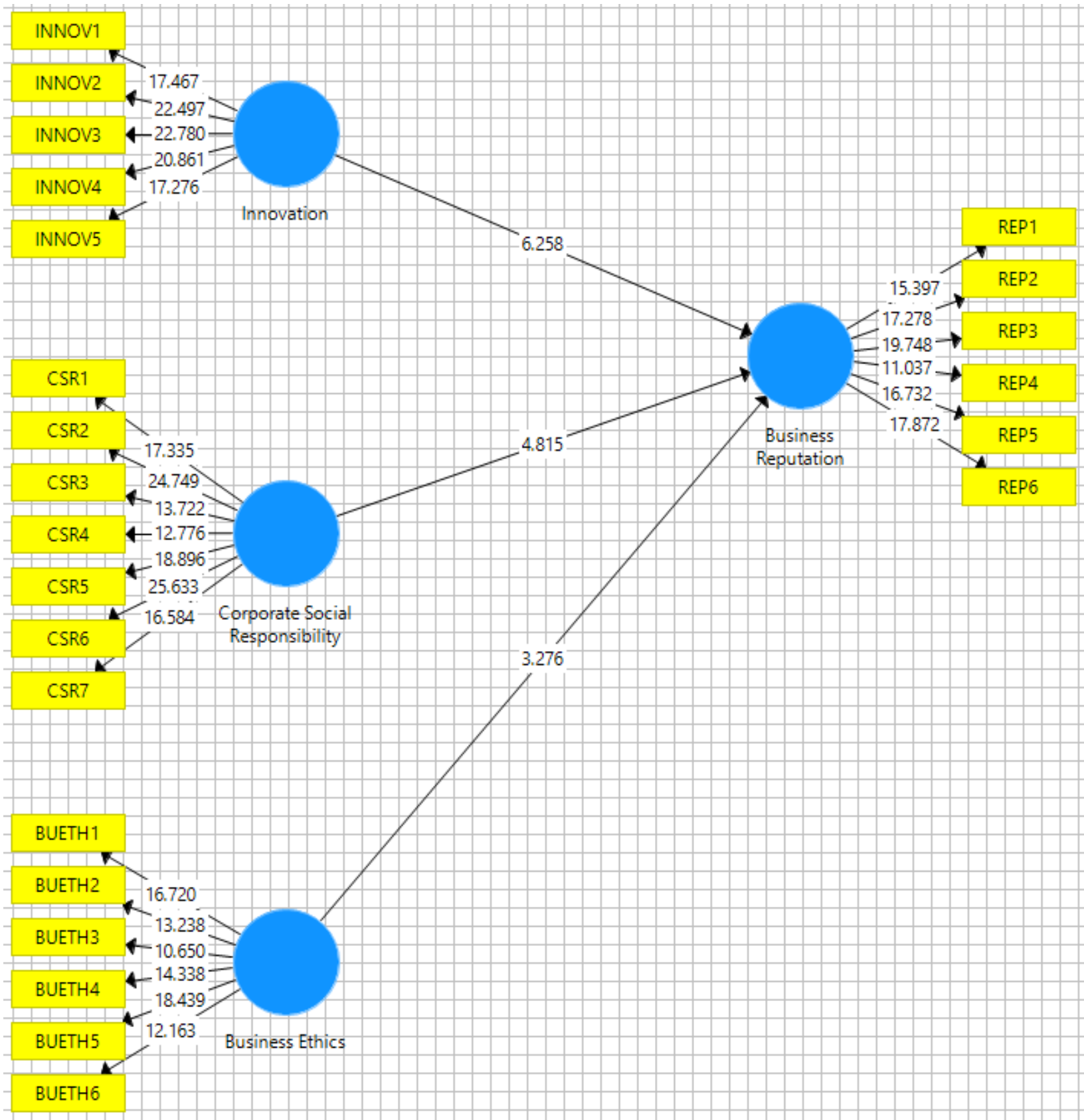

\section{Source: Researchers Computation (2020)}

Figure 4: Structural Equation Model Critical Path for the Level of Significance. 
European Journal of Accounting, Auditing and Finance Research

Vol.8, No.4, pp.1-17, April 2020

Published by ECRTD-UK

Print ISSN: 2053-4086(Print), Online ISSN: 2053-4094(Online)

\section{Discussion of Findings}

The first hypothesis examined the impact of corporate social responsibility on the reputation of listed firms in Nigeria for listed firms in Nigeria. The results show that corporate social responsibility has a positive relationship with the reputation of listed firms in Nigeria. In addition, there is evidence that corporate social responsibility has significant relationship with reputation of listed firms in Nigeria $(\mathrm{CSR}=0.654$, $\mathrm{t}$-test $=15.697, \mathrm{p}<0.05)$. It implied that corporate social responsibility is a significant factor influencing changes in the business reputation of listed firms in Nigeria.

The second hypothesis examined the controlling effect of innovation and business ethics on the relationship between corporate social responsibility and reputation of listed firms in Nigeria. The results show that business ethics, corporate social responsibility, and innovation have a positive relationship with the reputation of listed firms in Nigeria. Besides, there is evidence that business ethics, corporate social responsibility, and innovation have a significant relationship with the reputation of listed firms in Nigeria. It implies that business ethics, corporate social responsibility, and innovation were significant factors influencing changes in the reputation of listed firms in Nigeria.

Studies in conformity with the study include Amahalu, Ndubuisi, and Obi (2017) examined the link between Corporate Social Responsibility and financial performance and its implication on Deposit Money Bank in Nigeria. It is confirmed that corporate social responsibility has a positive and statistically significant effect on financial performance at 5\% significant level.Adamu (2015) examined the relationship between Corporate Social Responsibility and the company's financial performance. Secondary data obtained through content analysis of published companies' annual reports from 2009 to 2013. The results revealed that there a relationship between corporate social responsibility and company financial performance. Uadiale and Fagbemi (2012) examined the impact of CSR activities on financial performance measured with Return on Equity (ROE) and Return on Assets (ROA) of Nigerian listed firms. Secondary data obtained to determine the impact of CSR on financial performance. The results show that CSR has a positive and significant relationship with financial performance measures.

Benschop (2017) examined how investors value the assurance and subsequent assurance-related decisions concerning the scope, level, provider, and quality. Twenty-five (25) companies' data were extracted for the study. The results indicated a significant positive influence of assurance on firm value, and a positive relationship exists between the quality of assurance and firm value.Cherian, Umar, Thu, Nguyen-Trang, Sial and Khuong (2019) analysed the impact of corporate social responsibility reporting on the financial performance of Indian companies. Secondary data were used from 2011 to 2017 for 50 companies. The results show that there is a significant relationship between the performance of Indian companies and CSR. The results show that CSR is not only improving the firm's social value and reputation but also improves the 
profitability and performance of the companies. The result further stated that return on assets is significantly determined by corporate governance, customers, products, number of employees, and board size.

The researchers only considered financial information without taken cognizance of the nonfinancial information, which provides qualitative information about all the companies tested.Boafo and kokuma (2016) examined the impact of Corporate Social Responsibility on organizational Performance. Primary data were used by administering questionnaires to the management staff and other staff of Vodafone Ghana Ltd, and 20 respondents were randomly selected among management and staff through a simple random sampling technique. It was concluded that CSR has a substantial and positive impact on all performance indicators used in the literature reviewed, such as finance, organizational performance overtime, reputation, employee commitment, and brand differentiation.

It was recommended that employees should be involved in the CSR activities, and the rationale be communicated to them; companies should identify stakeholders' needs before taking CSR initiatives. The top management must understand the strategic financial benefits of CSR activities. Companies must include CSR initiates in their strategic plans to get higher support from top management, and companies should appoint someone to champion CSR initiatives within the business. The researchers only made use of one company; no quantitative information was taken into consideration, and the period covered was too short of making such a conclusion on organizational performance.

Simonescu and Dumitrescu (2018) examined the relation between Corporate Social Responsibility (CSR) practices and Company Financial Performance (CFP) for firms listed on the Bucharest Stock Exchange. The study investigated the effects of CSR policies from a multidimensional perspective towards the employees, clients, environment, local communities, social activities in relation to education and healthcare on corporate performance. The questionnaire was developed as a means to collect the data to identify the policies regarding the social responsibility practices of the companies listed on the BSE among the CSR activities that influence CFP. Cross-sectional regression models were used to analysed the data gathered. The study provided support for a positive link between CSR and CFP; companies should implement CSR policies regarding employees, environmental protection, and ethics as social practices. Further empirical findings show that companies responding to the CSR concept and those considering international standards and regulations for quality products and services in their business strategy enhance CFP.

\section{Implication of findings}

The research objectives have various implications for theory and practice. It supports and strengthens the accumulated body of empirical for the positive impact of corporate social responsibility dimensions on the reputation of listed firms. 
European Journal of Accounting, Auditing and Finance Research

Vol.8, No.4, pp.1-17, April 2020

Published by ECRTD-UK

Print ISSN: 2053-4086(Print), Online ISSN: 2053-4094(Online)

\section{Theoretical implications}

The theoretical implications of corporate social responsibility dimensions and its impact on the reputation of listed firms enable the management of the firms to make use of stakeholder theory and Legitimacy theory assumptions such as:

The implication of stakeholder theory stated that management should consider what stakeholders think about the organization, because they have different feelings and purposes about the operations of the firms due to the fact they see or view the world in different ways. The overall impressions they have added to the business reputation, which firms need to work on to create a good idea to the stakeholders (Valjakka, 2013).The implication of legitimacy theory to the firms stated that management should invest in activities that will benefit the society in where they operate. Such as donations to avoid engaging in economic activities that are harmful to the environment where they operate; that is the elimination of social costs (Internalising their negative externalities) (suchman, 1995).

\section{Practical implication}

The practical implications of the findings on the impact of corporate social responsibility dimensions on reputation of firms as stated below:

The management of organisation should be careful in engaging in any activities that may have a negative impacts on their business reputation which may affect the profitability of the firms in the long run where stakeholders lost confidence in them. Maintenance of a good business reputation must be the policy management should adopt when interacting with stakeholders whether customers are buying their products or investors are purchasing their stocks. When stakeholder's expectations are not meant the damage to business reputation will continue to manifest itself, which will decrease revenue and ability to attract financial capital will reduce, and it will also affect potential employees. To build organizational reputation can take several years, and to destroy may not take one month or a day (Minor \& Morgan, 2011).

\section{CONCLUSION AND RECOMMENDATION}

The study examined the relationship between corporate social responsibility and reputation of listed firms in Nigeria using Structural equation modeling. A total of 400 questionnaires were distributed, and 390 copies were returned, representing 98 percent return rate. Validity and the reliability of the research instrument of the study were done through Cronbach's Alpha; the composite reliability and average variance extracted was used. Cronbach's Alpha is greater than or equal to 0.7 . Also, the composite reliability is also greater than 0.7 , and the average variance extracted (AVE) is also greater than 0.5. From the results, it was discovered that all the research constructs validity and reliability tests were greater than the minimum acceptable level. Following the structural equation modeling, there is evidence that corporate social responsibility is a significant factor influencing business reputation in Nigeria. Also, the second hypothesis which tests the controlling effect of innovation, business ethics, and corporate social 
European Journal of Accounting, Auditing and Finance Research

Vol.8, No.4, pp.1-17, April 2020

Published by ECRTD-UK

Print ISSN: 2053-4086(Print), Online ISSN: 2053-4094(Online)

responsibility on business reputation is also statistically significant. It implies that business ethics, corporate social responsibility, and innovation were significant factors influencing changes in the reputation of listed firms in Nigeria.

The study recommends that firms should continue to give back to their immediate community to enhance their business reputation. It also strongly recommended that listed companies in Nigeria should concentrate on their business ethics and innovation as it promotes business reputation.

\section{References}

Barry, N. P. (2000). Controversy: Do corporations have any responsibility beyond making a profit? Journal of Markets \& Morality 3(1), 100-107.

Boafo, N.D. \& kokuma (2016). The impact of corporate social responsibility on organisational performance. European Journal of Business and Management, 8(22): ISSN 2222-1905 :ISSN 2222-2839

Carroll, A. \& Buchholtz, A. (2003). Business and society: Ethics and stakeholder management. Cengage Learning, Stamford.

Carroll, A. B., \& Shabana, K. M. (2010). The business case for corporate social responsibility: A review of concepts, research and practice. International Journal of Management Reviews. 85- 105.

Carroll, A. B. (1979). A three-dimensional conceptual model of corporate social performance. Academic of management Review, 4, 497-505.

Cherian, J., Umar, M., Thu, P., Nguyen-Trang, T., Sial, M. S. \& Khuong, N. V. (2019). "Does corporate social responsibility affect the financial performance of the manufacturing sector? Evidence from an emerging economy," Sustainability, MDPI, Open Access Journal, 11(4) 1-14.

Cho, S.J., Chung, C.Y. \& Young, J. (2019). Study on the relationship between CSR and financial performance. Sustainability, 11, 343.

Fayad, A.A., Ayoub, R. \& Ayoub, M. (2017). Causal relationship between CSR and FB in banks. Arab Economic and Business Journal, 12(2) 93-99. ISSN 2214-4625, http://dx.doi.org/10.1016/j.aebj.2017.11.001

Fombrun, C. J., Gardberg, N. A. \& Barnett, M. L. (2000). Opportunity platforms and safety nets: Corporate citizenship and reputational risk. Business and Society Review, 105(1), 85-106.

Friedman, M. (1970). A friedman doctrine - The social responsibility of business is to increase its profits, The New York Times Magazine, 32 - 33

Fuller, S. (2013). Never let a good crisis go to waste': moral entrepreneurship, or the fine art of recycling evil into good. Business Ethics: A European Review. 22(1).

Gallardo-Vazquez, D., \& Sanchez-Hernandez, M. I., (2014). Measuring corporate social responsibility for competitive success at a regional level. J. Clean. Prod. 72(14) e22.

Goel \& Ramanathan (2014). As cited in business ethics and corporate social responsibility - Is there a dividing line? symbiosis institute of management studies annual research conference (SIMSARC13). Procedia Economics and Finance, 11, 49 - 59 
European Journal of Accounting, Auditing and Finance Research

Vol.8, No.4, pp.1-17, April 2020

Published by ECRTD-UK

Print ISSN: 2053-4086(Print), Online ISSN: 2053-4094(Online)

Goel, M., Sanghvi, T. \& Dahiya, K. (2013). Role of corporate social responsibility in entrepreneurship development. Unpublished.

González-Ramos, M. I., Donate, M. J. \& Guadamillas, F. (2014). Technological posture and corporate social responsibility: Effects on innovation performance, environmental. Engineering and Management Journal, 13(10), 2497-2505.

Hillman, A. J. \& Keim, G. D. (2001). Shareholders value, stakeholder management, and social issues: what's the bottom line? Strategic Management journals, 22, 125-139.

Jamali, D. \& Mirshak, R. (2007). Corporate social responsibility: Theory and practice in a developing country context. J. Bus. Ethics, 72, 243-262.

Jibril, R. S., Dahiru, A. Y., Muktar, J. \& Bello, M. M. (2016). Corporate social responsibility and financial performance of quoted deposit money banks in Nigeria. Research Journal of Finance and Accounting, 7(13), 39-48

Khojastehpour, M. \& Johns, R. (2014). The effect of environmental CSR issues on corporate/brand reputation and corporate profitability. European Business Review, 26(4), 330-339, DOI: 10.1108/EBR-03-2014-0029

Masaka, D. (2008). Why enforcing corporate social responsibility (CSR) is morally questionable. EJBO Electronic Journal of Business Ethics and Organization Studies, 13(1)

Minor, D. \& Morgan, J. (2011). CSR as reputation insurance: Primum non nocere. California Management Review, 53(3), 40-59, DOI: 10.1525/cmr.2011.53.3.40

Morsing, M. \& Perrini, F. (2009). CSR in SMEs: do SMEs matter for the CSR agenda? Bus. Ethics A Eur. Rev. 18(1), 1e6.

Mustafa, S. A., Othman, A. R. \& Perumal, S. (2012). Corporate Social Responsibility and Company performance in the Malaysian context.Social and Behavioral sciences, 65, 897905.

Park, J., Lee, H. \& Kim, C. (2014). Corporate social responsibilities, consumer trust and corporate reputation: South Korean consumers' perspectives. Journal of Business Research, 67, 295-302.

Petkeviciene, M. S. (2015). CSR Reasons, Practices and Impact to Corporate Reputation. Procardia -Social and Behavioral Sciences 213:503-508. DOI: 10.1016/j.11.441

Quinn, R.E. and Rohrbaugh, J. (1983), "A spatial model of effectiveness criteria: towards acompeting values approach to organizational analysis. Management Science, 29(3), 36377

Richard, P.J., Devinney, T.M., Yip, G.S. \& Johnson, G. (2009). Measuring organisational performance: towards methodological best practice. J. Manag. 35(3), 718-804.

Rodin (2005). Political and Economic Arguments for Corporate Social Responsibility: Analysis and a Proposition regarding the CSR Agenda. Journal of Business Ethics86(4). 417-428

Saez-Martínez, F.J., Gonzalez-Moreno, A. \& Hogan, T. (2014). The role of the University in ecoentrepreneurship: Evidence from the Eurobarometer Survey on Attitudes of European Entrepreneurs towards Eco-innovation. Environ. Eng. Manag. J., 13, 2451-2459. 
Vol.8, No.4, pp.1-17, April 2020

Published by ECRTD-UK

Print ISSN: 2053-4086(Print), Online ISSN: 2053-4094(Online)

Selvam, M., Vasanth, V., Lingaraja, K. \& Marxiaoli, S. (2016). Determinants of firm performance: A subjective model. International Journal of Social Science Studies 4(7); ISSN 2324-8033 E-ISSN 2324-8041

Simionescu, L.N. \& Dumitrescu, D. (2018). Empirical study towards corporate socialresponsibility practices and company financial performance. Evidence for companies listed on the Bucharest Stock Exchange. Sustainability, 10, 3141; doi:10.3390/su10093141

Valjakka, M. (2013). CSR and company reputation, Case study of Nike. PhD thesis, University of Wolverhampton

Veh A., Gobel M., \& Vogel., R. (2018). Corporate reputation in management research: a review of the literature and assessment of the concept, https://link.springer.com/article/10.1007

Wozniak, A. (2011). The missing subject found in the subject who does the thinking: Kierkegaard, the ethical and the subjectivity of the critical theorists. Business Ethics: $A$ European Review 20(3).

Zhou, S., Quan, X., \& Jiang, W. (2012). Corporate social responsibility and sustainable development in China: literature review and case analysis. Journal of Supply Chain and Operations Management, 10, 54-65. 